\title{
Lightly threaded clusters from Australia and New Zealand
}

\section{轻轻交织的来自澳大利亚与新西兰的作品}

\author{
Introduction by Stacey Bush and Deborah Green \\ Stacey Bush与Deborah Green
}

Part way through 2018, the editorial team at Creative Arts in Education and Therapy (CAET) tested out an inquiry: Would we, the arts therapy folks down-under, like to contribute to the journal? The brief was very open and invited us to allow the arts to lead as we explored our experiences of being artists, therapists, educators, and researchers. A flurry of Kiwi and Aussie activity followed, the result of which you see threaded together in the sections that follow. This blend of creative and scholarly pieces speaks to the therapeutic practice, research and educational processes alive with the broader context of postgraduate Arts Therapy education in New Zealand and Australia. Contributors include Whitecliffe College of Arts and Design in Auckland and Christchurch, New Zealand, The MIECAT Institute in Melbourne, Australia, CATRU (Creative Arts Therapies Research Unit), University of Melbourne, Australia, and LaTrobe University in Melbourne, Australia. Educators and students have contributed works that range from poems and yarn wrapped sticks to longer research papers.

在2018年结束之时，CAET编辑部询问我们：来自澳大利亚与新西兰的艺术 治疗人士，是否愿意为期刊撰写文章? 简函非常开放地邀请我们让艺术带领我 们探索作为艺术家、治疗师、教育者以及科研人员的经历。于是我们这些新西 兰和澳大利亚的同行就进行了一系列的活动; 活动的结果可以从随后汇编的章 节读到。这篇兼具创造性和学术性的文章与新西兰和澳大利亚存在的研究生艺 术治疗教育中的治疗实践、科研和教育过程相对应。作者包括新西兰奥克兰和 克莱斯特彻奇的Whitecliffe艺术与设计学院、澳大利亚墨尔本的MIECAT院校、 澳大利亚墨尔本大学的创造性艺术治疗研究部门CATRU和澳大利亚墨尔本的 LaTrobe大学。这些学校师生的投稿作品范围广泛，从诗歌、裹线木棍到篇幅较 长的科研文章。

Tasked with clustering this diverse body of work into three groupings, we have spent some time with each of these wonderfully varied pieces. We approached tentatively, seeking to meet these works lightly and with an attitude of openness, and this allowed a growing sense of the key thread of intention in each piece to rise to the surface of awareness. What is very striking is that each piece laces together intentions of exploring arts in/as therapeutic practice, arts in/as education practice, and also arts in/as research practice. These three strands of intentionality run through each submission in different ways and with different intensities and strengths. By way of their interconnectedness and integration, these threads work to hold together this diverse range of submissions.

Honouring the spirit in which the pieces were created, we take the time to ponder our endeavour to cluster this work. 
我们被委以将这些主体多样化的文章分到三组里，于是花时间与这些奇妙而 不同的每一个作品接触。我们尝探性地靠近，试图以一种开放的态度，轻柔地 接触这些作品，而这也使得每一件作品中的创作主线慢慢地浮现到意识的表 面。使人感到惊奇的是，每一件作品的创作意图不约而同交织于将探索艺术作 为治疗或治疗中的目的、作为教育或在教育中的目的，以及作为科研或在科研 中的目的。这三种创作的意向性以不同的方式，强度和力量贯穿在每一份递交 的作品中。通过它们之间的相互连接与融合，这些作品将多样性承接在一起。

为了对每一件作品的灵魂表示尊重，我们花一些时间仔细思考，尽力为作品 分类。

Deborah: I am called to respond to my immersion in the pieces by walking in the hills behind my home in Lyttelton, New Zealand. I notice and photograph pathways and tracks threaded through the long grass, bushes and trees. I collect sticks, one for each piece in this bricolage. At home I layer together the images into a collage which speaks to me of tracks being made by walking. And I interweave and partially wrap the sticks these I hang in a vine just beginning to taste Spring and, stepping back, I see a strange whimsical nest held lightly together. I breathe in these metaphors that reference how, south of the equator, we are living our practice into being.

Deborah : 我受到召唤以漫步在新西兰利特尔顿自家屋后山丘中的方式回应我 在这些作品中的沉浸。我注意到并拍下草木树灌贯穿丛生的通道和路径。我收集 木棍，每一根都成为这个构筑中的一部分。在家中，我将照片叠影，映照着因为 走过而形成的路径。我交织并将木棍部分缠绕，然后将它们挂在一条刚刚展现春 天意味的葡萄藤中；退后一步，我看见一个奇怪搞笑的鸟窝。我感到这些充满生 机的比喻代表了我们怎样在南半球将我们的实践活成生活的一部分。

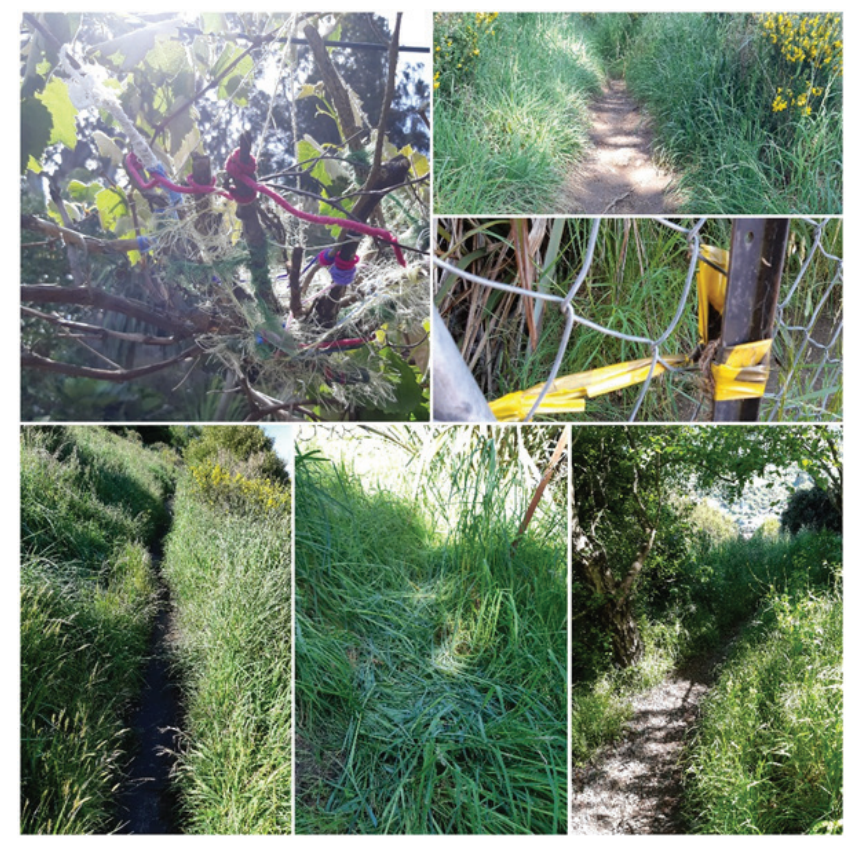

Deborah:Tracks, sticks and nests路径，木棍与乌窝(digital photograph, 2018) 
Stacey: I meet this offering from you Deb, with gratitude for the strong sense evoked in me of tracks co-created, threads enmeshed, and light holding. I too take a walk, wondering how to respond as I wander through inner city streets of Fitzroy. A van window catches my eye, at first, I see tracings like pathways, then another layer becomes apparent in a reflection of all that surrounds and engages us in our ongoing lived experiencing.

Stacey：我通过你，Deborah，与这个作品相遇，并对这些一同创造出来的路 径、交杂在一起的线条以及轻柔的抱持充满感激。我也外出散步，并当我漫步 经过菲滋洛伊城市中街道时思考如何作出回应。一个小客车窗吸引了我的眼 球。最初，我看到一条条如同通道的线条，接着，另一个层面显现出来，映射 出所有紧密相联并使我们融入不停息的生活经历的一切。

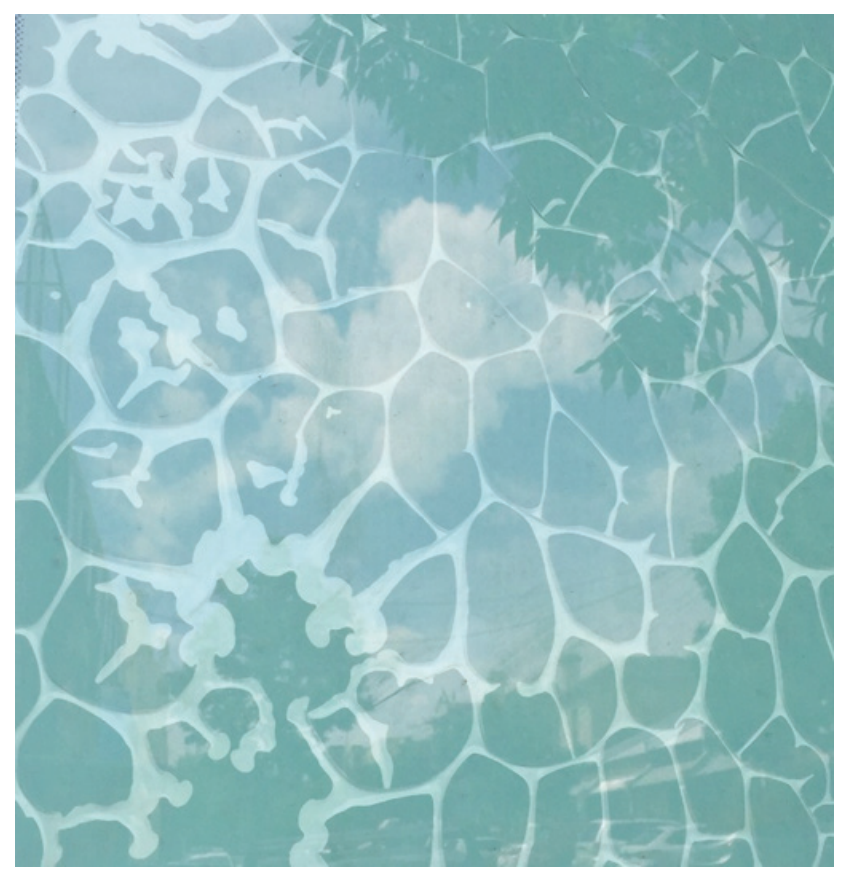

Stacey:Pathways, layers, and reflections通道，层次，与倒影(digital photograph, 2018)

What follows is the first of the three clusterings of articles. This initial cluster is gathered together under the title Arts in/as therapeutic practice and is prefaced with ashort introduction in the form of a dialogue between Deborah and Stacey. The two sections that follow feature further conversations introducing the clusters exploring Arts in/as education practice and Arts in/as research practice.

接下来就是三组文章中的第一组。这第一组以“在治疗实践中的和作为治疗 实践的艺术" 这个题目聚集，并以Deborah和Stacey间的一个对话作为简短的介 绍。接下来的两各版块将刊出更多的对话，介绍 “在教育实践中的和作为教育 实践的艺术" 以及 “在科研实践中的和作为科研实践的艺术" 两个组。 